\title{
ENERGIA EÓLICA: UM ESTUDO SOBRE A PERCEPÇÃO AMBIENTAL NO MUNICÍPIO DE CURRAIS NOVOS/RN
}

\author{
Sanclair Solon de Medeiros \\ Acadêmico do Curso de Gestão Ambiental do IFRN - Campus Currais Novos \\ sanclairfas@yahoo.com.br \\ Francisco Nixon Pereira de Macedo Aquino \\ Acadêmico do Curso de Gestão Ambiental do IFRN - Campus Currais Novos \\ nixon.uab@hotmail.com \\ Paulo Gustavo Felix de Barros \\ Acadêmico do Curso de Gestão Ambiental do IFRN - Campus Currais Novos \\ gustavobarros2@hotmail.com \\ Lilyan Louise de Medeiros Moura \\ Acadêmica do Curso de Gestão Ambiental do IFRN - Campus Currais Novos \\ lilylou6@hotmail.com \\ Antônio Eduardo de Araújo \\ Acadêmico do Curso de Gestão Ambiental do IFRN - Campus Currais Novos \\ araeduardo@infraero.gov.br
}

\begin{abstract}
RESUMO
O estudo, ora apresentado, tem como objetivo principal compreender a percepção ambiental que a população tem a respeito da instalação, utilização, danos ao meio ambiente e consciência ambiental com relação às energias renováveis, neste caso a eólica. O recorte espacial adotado para o estudo é o município de Currais Novos que pela sua formação geomorfológica e climatológica apresenta condições suficientes para a instalação e utilização da energia eólica de forma a modificar a matriz energética do município. Todavia é necessário considerar o que a população do município sente a respeito de tais atividades, pois é a partir de tal percepção que se pode modificar significativamente a realidade na qual se está inserida.
\end{abstract}

PALAVRAS-CHAVE: Energia Eólica, Percepção Ambiental, Currais Novos.

\section{WIND ENERGY: A STUDY ON THE ENVIRONMENTAL PERCEPTION ON LOCAL AUTHORITY OF CURRAIS NOVOS/RN}

\begin{abstract}
The study, now presented, takes it as a main objective of understands which the environmental perception that the population has as to the installation, use, damages to the environment and environmental conscience regarding the renewable energies, in this case the wind energy. The space cutting out adopted for the study is Currais Novos that for his geomorphology and climatology presents sufficient conditions for the installation and use of the wind energy in the form to modify the energetic womb of the council. However it is
\end{abstract}


necessary to think what the population of the council feels as to such activities, since it is from such a perception from which it is possible to modify significantly fact which is inserted.

KEY WORDS: Wind Energy, Environmental Perception, Currais Novos. 


\section{ENERGIA EÓLICA: UM ESTUDO SOBRE A PERCEPÇÃO AMBIENTAL NO MUNICÍPIO DE CURRAIS NOVOS/RN}

\section{INTRODUÇÃO}

"A energia que move o mundo tem cor escura, é um recurso finito e altamente poluente." (Trigueiro apud Improta, 2008).

A crescente demanda por soluções que visem à redução do uso de energias não-renováveis - "poluidoras", aliada a crise energética mundial e o aquecimento global, tem levado a humanidade a repensar seus hábitos de consumo e substituir a utilização das energias poluidoras, geradas por combustíveis fósseis, por energias renováveis. Neste sentido, torna-se fundamental para a sustentabilidade do Planeta e qualidade de vida humana a busca de estudos que conduzam a criação de tecnologias capazes de promover o maior aproveitamento de fontes de energia não poluidoras. No Rio Grande do Norte é possível identificar experiências interessantes no que diz respeito a tal problemática, como o caso dos municípios de Macau e Rio do Fogo.

Entende-se por energias renováveis, não poluidoras, também denominadas limpas, segundo o Instituto de Desenvolvimento Sustentável e Energia Renováveis (2009), as captadas de fontes naturais capazes de regeneração por meios naturais e assim inesgotáveis.

O objetivo deste estudo é compreender qual a percepção ambiental que a população Curraisnovense tem a respeito da instalação, utilização, danos ao meio ambiente e consciência ambiental com relação às energias renováveis, neste caso a eólica.

Para Gil (2002), pode-se definir pesquisa como o procedimento racional e sistemático que tem como objetivo proporcionar respostas aos problemas que são propostos [...] A pesquisa é desenvolvida mediante o concurso dos conhecimentos disponíveis e a utilização cuidadosa de métodos, técnicas e outros procedimentos científicos. Sendo assim, para se fundamentar o referido estudo revisou-se a literatura acerca do tema e serão realizadas entrevistas estruturadas de amostra aleatória dos munícipes para obtenção dos objetivos propostos o que tipifica o referido estudo como de cunho exploratório.

Para a realização e aplicação dos questionários foi realizada cálculo de amostragem probabilística considerando a totalidade da população da cidade onde se definiu a mesma com aproximadamente 145 pessoas utilizando-se a fórmula de tamanho amostral com um intervalo de confiança de $95 \%$.

O município de Currais Novos, no Rio Grande do Norte, recorte espacial adotado, situa-se na região do Seridó, suas características segundo o Instituto de Defesa do Meio Ambiente - IDEMA ${ }^{1}$ (2006), as estimativas do Instituto Brasileiro de Geografia e Estatística - IBGE ${ }^{2}$ (2009) e a Clima Tempo ${ }^{3}$, são as seguintes: 
Quadro 01 - Caracterização do município de Currais Novos

\begin{tabular}{|l|l|}
\hline \multicolumn{1}{|c|}{ ASPECTO } & \multicolumn{1}{c|}{ CURRAIS NOVOS } \\
\hline População $^{2}$ & 42.066 \\
Área $^{1}$ & $864,34 \mathrm{~km}^{2}$ \\
Clima $^{1}$ & Quente e semi-árido \\
Vegetação $^{1}$ & Caatinga Hiperxerófila \\
Solo $^{1}$ & Litólico Eutrófico \\
Hidrologia $^{1}$ & Bacia do Rio Piranhas Assu \\
Ventos $^{3}$ & 16 km/hora \\
\hline
\end{tabular}

Fonte: IDEMA, 2006; IBGE, 2009; Clima Tempo, 2009.

\section{HISTÓRICO DA ENERGIA EÓLICA}

Segundo Olinto (2008), o termo eólico vem do latim aeolicus, pertencente ou relativo a Éolo, deus dos ventos na mitologia grega.

Os moinhos de ventos são os mais antigos equipamentos de utilização da energia eólica da história, os mesmos foram introduzidos na Europa em meados do século XVII, e no ano de 1750 já registrava a instalação de 8.000 e 10.000 deles, respectivamente na Holanda e na Inglaterra suas principais utilizações eram bombeamento de água, moagem de grãos e outras atividades que se utilizavam da energia mecânica produzida. Data-se ainda que seu declínio ocorreu com o surgimento do motor a vapor, durante a revolução industrial, e foi mais acentuado após a aparecimento dos combustíveis fósseis como, também, da energia hidráulica. No tocante a produção de energia a partir do vento (eólica), as primeiras tentativas ocorreram no século XIX, mas foi somente com a Crise Internacional do Petróleo que houve o interesse e investimentos para a viabilização em escala comercial. Registra-se que somente no século seguinte, em 1976, a instalação da primeira turbina eólica na Dinamarca. (HINRICHS \& KLEIBANCH Apud GUERRA, 2007)

\section{ENERGIA EÓLICA NO MUNDO}

A Agência Nacional de Energia Elétrica - Aneel (2008), define energia eólica como sendo a energia cinética contida nas massas de ar em movimento (vento). $\mathrm{O}$ vento por sua vez surge com o aquecimento desigual da superfície da Terra. (OLINTO, 2008)

Seu aproveitamento ocorre por meio da conversão da energia cinética de translação em energia cinética de rotação, com o emprego de turbinas eólicas, também denominadas aerogeradores, para a geração de eletricidade, ou cata-ventos e moinhos, para trabalhos mecânicos como bombeamento d’água.

Paul Lacour, Físico, Meteorologista e Inventor, é considerado o criador do aerogerador, tal feito foi publicado em 1904 no jornal Wind Electric de sua autoria.

Data-se de 1888 o desenvolvimento do primeiro aerogerador por Charles Brush (18491929), proprietário da Brush Electric, situada em Cleveland - Ohio - EUA, a turbina, com capacidade de produção de $12 \mathrm{Kw}$, era formada por 144 pás de madeira de $17 \mathrm{~m}$ de diâmetro 
e operou por 20 anos armazenando energia em baterias (PASSOS, 2008), como mostra a figura 1.

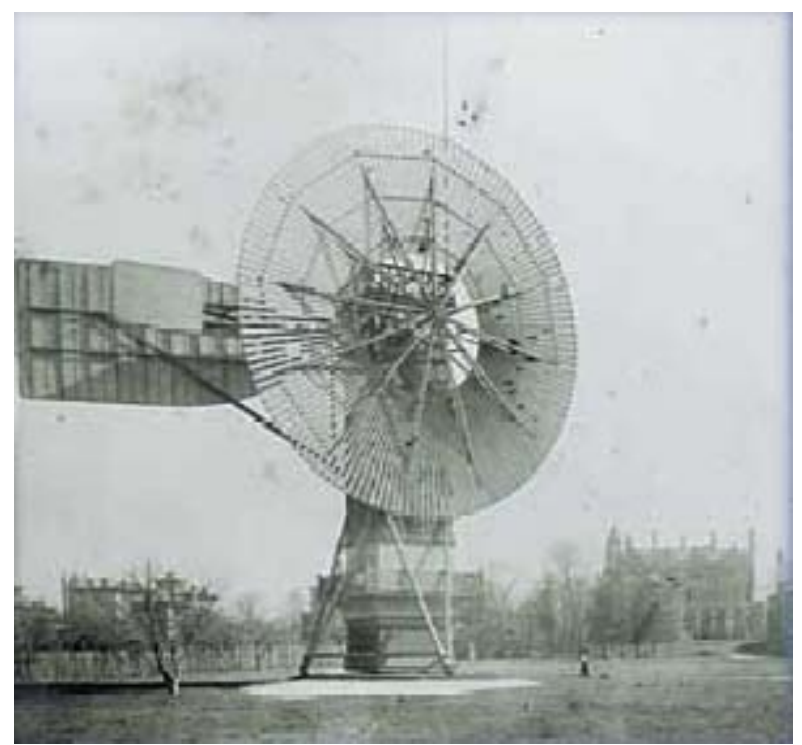

Figura 1 - Primeiro aerogerador desenvolvido por Brush

Segundo a Agência Nacional de Energia Elétrica - ANEEL (2008), a capacidade instalada mundial da energia eólica aumentou 1.155\% entre 1997 e 2007, passando de 7,5 mil para 93,8 mil MW, como registra a World Wind Energy Association (WWEA) tendo como principal país produtor desta energia a Alemanha com um percentual de $23,7 \%$ da energia eólica total produzida no mundo. O Brasil ocupa a $25^{a}$ posição com 0,3\%. Dados que mostram que o Brasil, devido a suas características favoráveis a tal energia, tem um longo caminho a percorrer enquanto produtores de energias renováveis, neste caso a eólica. A ANEEL cita ainda, que não existem estudos precisos referentes a demanda mundial de produção de energia eólica, mas estimativas apontam que o potencial eólico bruto no planeta seja da ordem de 500 mil TWh (terawatts-hora) por ano, embora, por restrições socioambientais, apenas 10\% sejam tecnicamente aproveitáveis. Ainda assim, 50 mil TWh por ano correspondem a mais de $250 \%$ da produção mundial total de energia elétrica em 2007, que foi de 18,9 mil TWh. 


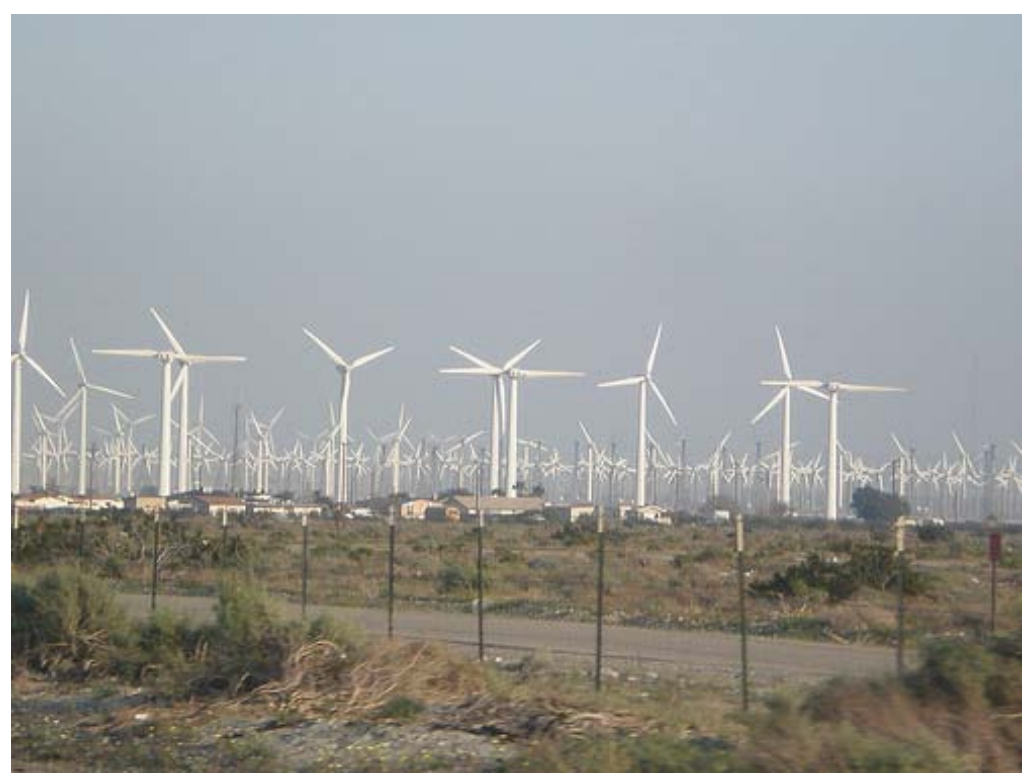

Figura 2 - Parque Eólico da Espanha - 2ª Maior produtora de Energia Eólica do Mundo

Atualmente o maior aerogerador do mundo está instalado na Alemanha com diâmetro de $126 \mathrm{~m}$ e uma capacidade de produzir 20 milhões de kilowatts hora/ano, como mostrado na figura 3.

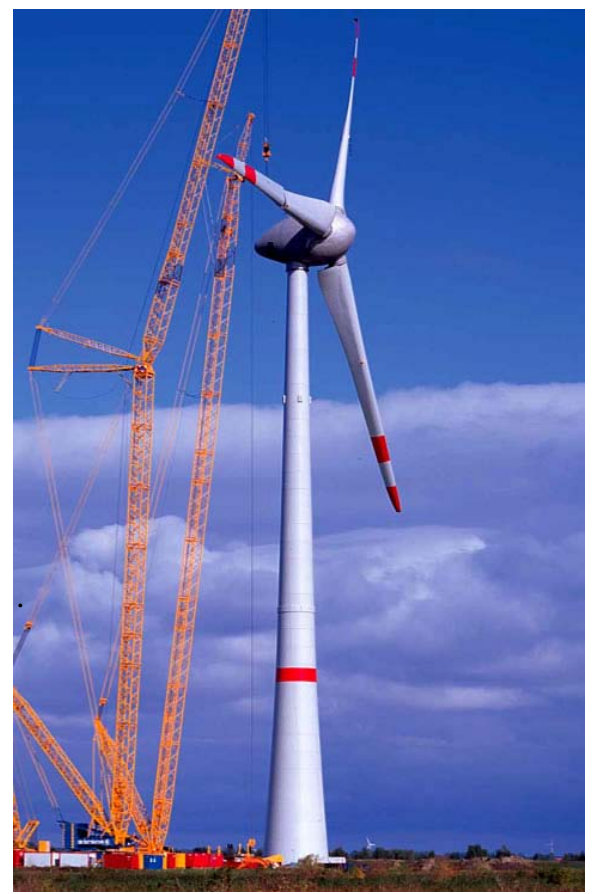

Figura 3 - Maior Aerogerador do mundo

\section{ENERGIA EÓLICA NO BRASIL}

No Brasil, a instalação da primeira turbina eólica aconteceu no Arquipélago de Fernando de Noronha, 1992, em um convênio realizado pelo Grupo de Energia Eólica da Universidade Federal de Pernambuco, financiado por um Instituto de Pesquisas 
Dinamarquês - Folkcenter em parceria com a Companhia Energética de Pernambuco CELPE. A referida turbina possui um gerador assíncrono de $75 \mathrm{~kW}$, rotor de $17 \mathrm{~m}$ de diâmetro e torre de $23 \mathrm{~m}$ de altura, na época de sua instalação a capacidade de produção era de cerca de $10 \%$ da energia gerada na Ilha, perfazendo uma economia de aproximadamente 70.000 litros de óleo diesel por ano. A segunda turbina de Fernando de Noronha foi instalada em maio de 2000 entrando em operação em 2001. O projeto foi realizado pelo Centro Brasileiro de Energia Eólica, com a colaboração do RISØ Laboratório Nacional da Dinamarca, e financiado pela ANEEL. As duas turbinas geram atualmente até $25 \%$ da eletricidade consumida no Arquipélago, assim esses projetos fizeram de Fernando de Noronha o maior sistema híbrido (eólico-diesel) do Brasil, que consiste na geração de energia tanto eólica como a diesel por meio de geradores (ANEEL, 2006). A primeira central eólica no país foi projetada pela CEMIG/CBEE, e instalada em 1994 em Minas Gerais dotada de 4 turbinas Tacke, 250kW (MACEDO, 2002).

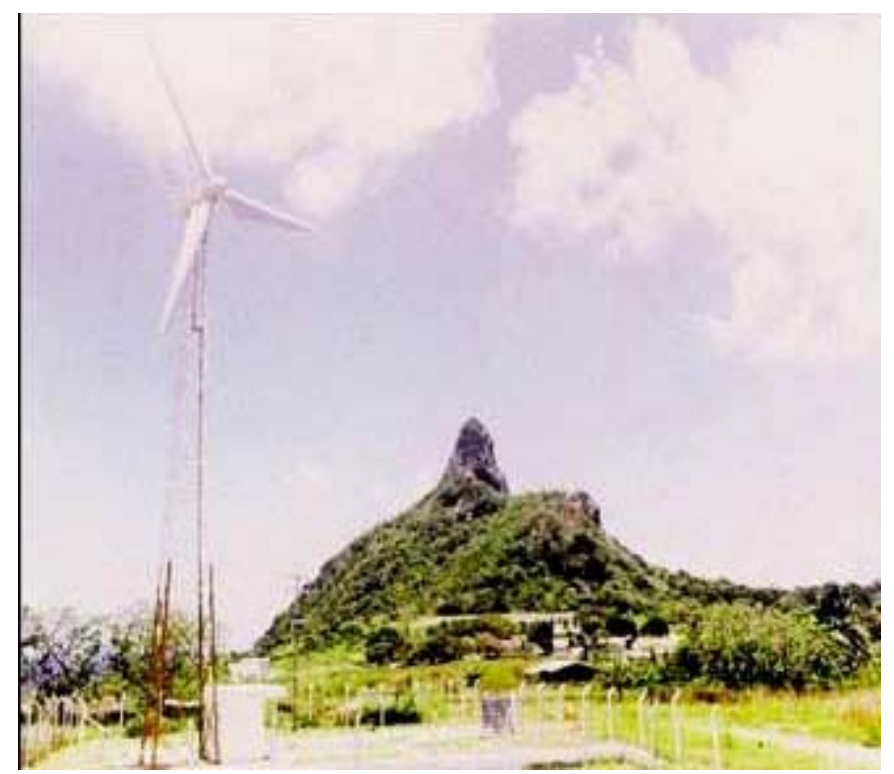

Figura 4 - Primeira turbina eólica do Brasil em Fernando de Noronha

Observa-se com a instalação dos primeiros aerogeradores no Brasil, o surgimento de significativo interesse de instituições de pesquisa (nacionais e internacionais) e instituições de ensino superior na realização de estudos para melhor aproveitas, devido as condições propícias, a instalação destes parques e assim, contribuir para o aumento dos parques eólicos no Brasil. Tal afirmativa pode ser comprovada tendo em vista os projetos de geração de energia com base eólica aprovados pela ANEEL (2009), são eles: CE 16,2MW; PE 0,6MW; MG 1MW e PR 2,5MW totalizando atualmente uma produção de 20,3MW.

Após a efetivação dos primeiros aerogeradores no Brasil, observa-se de acordo com Feitosa (2009), que é crescente o número de projetos com o objetivo de produção de energia eólica no País. Tal crescimento dá-se principalmente pelas características favoráveis de vento, o autor apresenta ainda uma comparação entre a vazão do rio São Francisco e a velocidade média dos ventos típicos do litoral do nordeste. Observa-se na figura 5 apresentada em seguida, que os ventos são superiores à vazão, principalmente nos meses de seca podendo-se observar nos meses de maio a agosto uma acentuada redução da vazão do rio. 


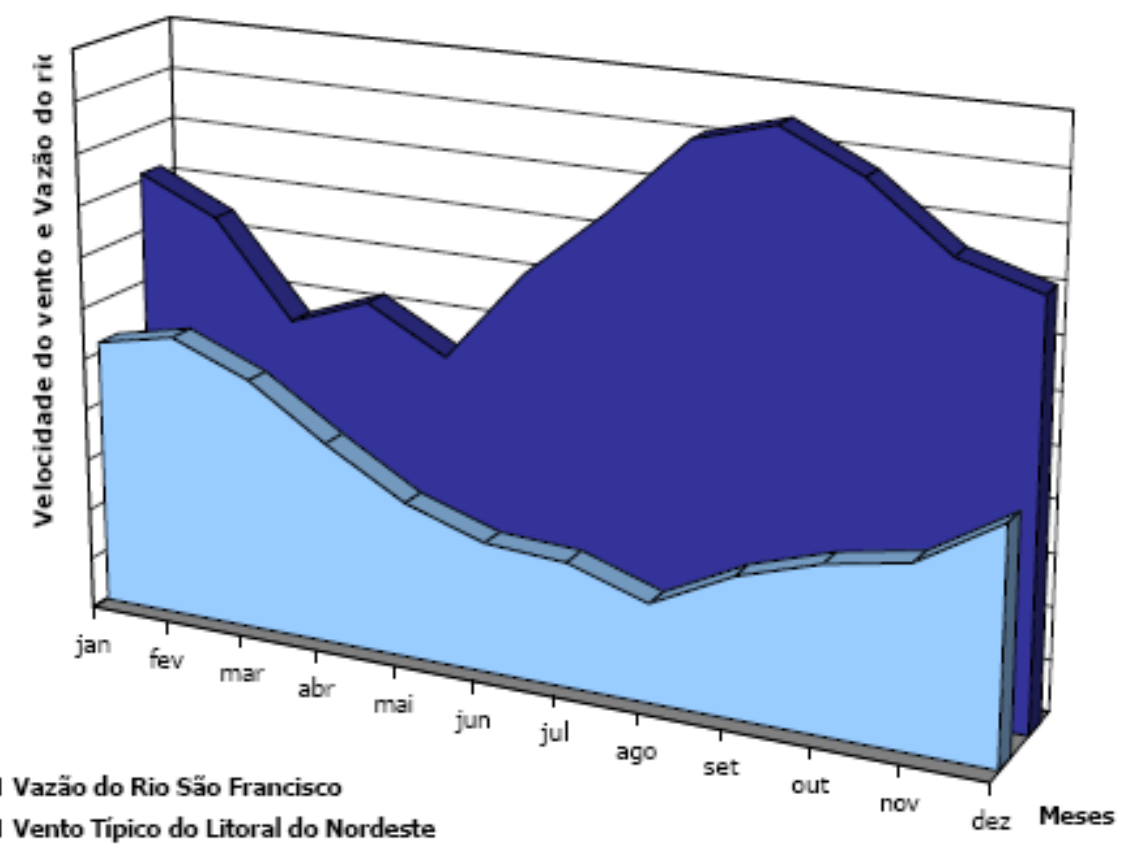

Figura 5 - Comparação entre a vazão do Rio São Francisco e os ventos típicos de litoral.

\section{O RIO GRANDE DO NORTE E A ENERGIA EÓLICA}

Atualmente no Rio Grande do Norte, existem dois parques eólicos instalados situados em Rio do Fogo, a 80 km da capital do Estado, e o de Macau.

O parque eólico de Macau, opera desde 2003, foi o primeiro no Estado, com produção de 1,8MW, o mesmo foi desenvolvido entre uma parceria da Petrobrás com a Wobben Windpower, subsidiária da alemã Enercon. Com investimentos de ordem de R\$ 6 milhões para a instalação de 3 aerogeradores. A produção do referido parque é conectada a rede de distribuição da COSERN e será utilizada pela Petrobrás em suas unidades operacionais no local. (PETROBRÁS, 2003).

Em Rio do Fogo, o parque eólico, foi desenvolvido com recursos do Programa de Incentivo às Fontes Alternativas de Energia Elétrica - PROINFA em parceria com a Iberdrola Renováveis, o Instituto Nacional de Colonização e Reforma Agrária - INCRA, os proprietários de terrenos na área e Autoridades, o parque eólico tem gerado atualmente 49.300 kilowatts que são conectados a rede de distribuição da COSERN e é suficiente para abastecer 75.000 habitantes considerando um consumo médio de 2Mwh por habitante/ano. (GABARIAN, 2008) 


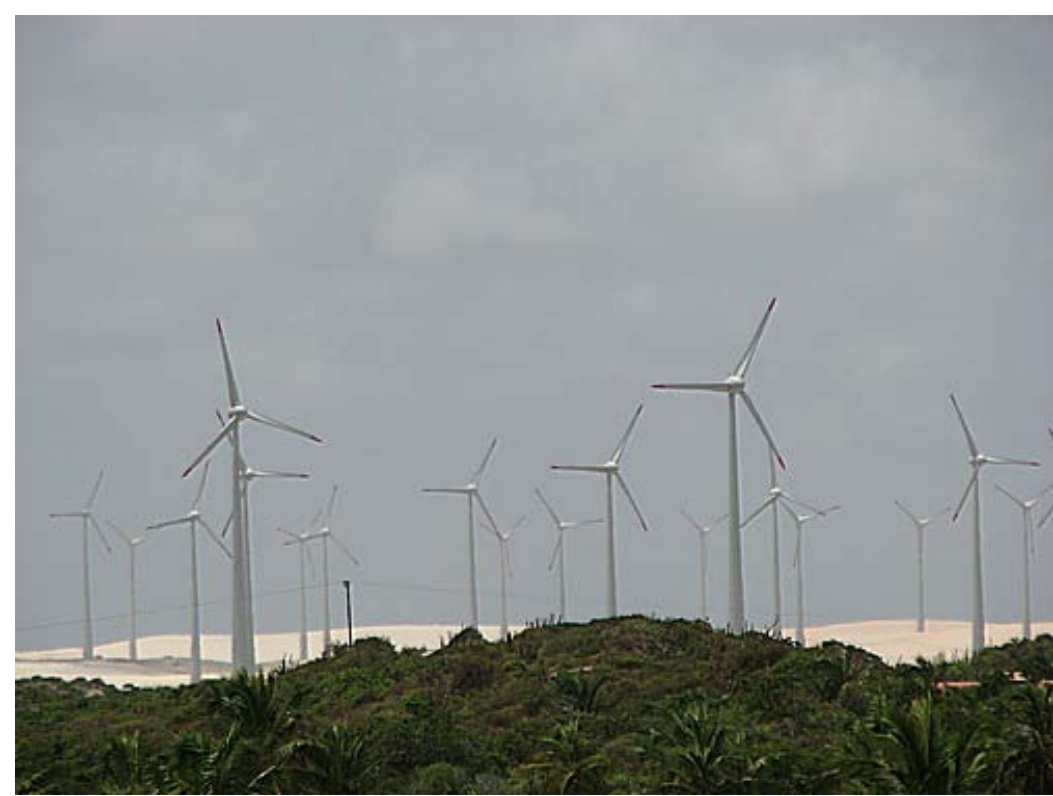

Figura 6 - Parque Eólico de Rio do Fogo / RN

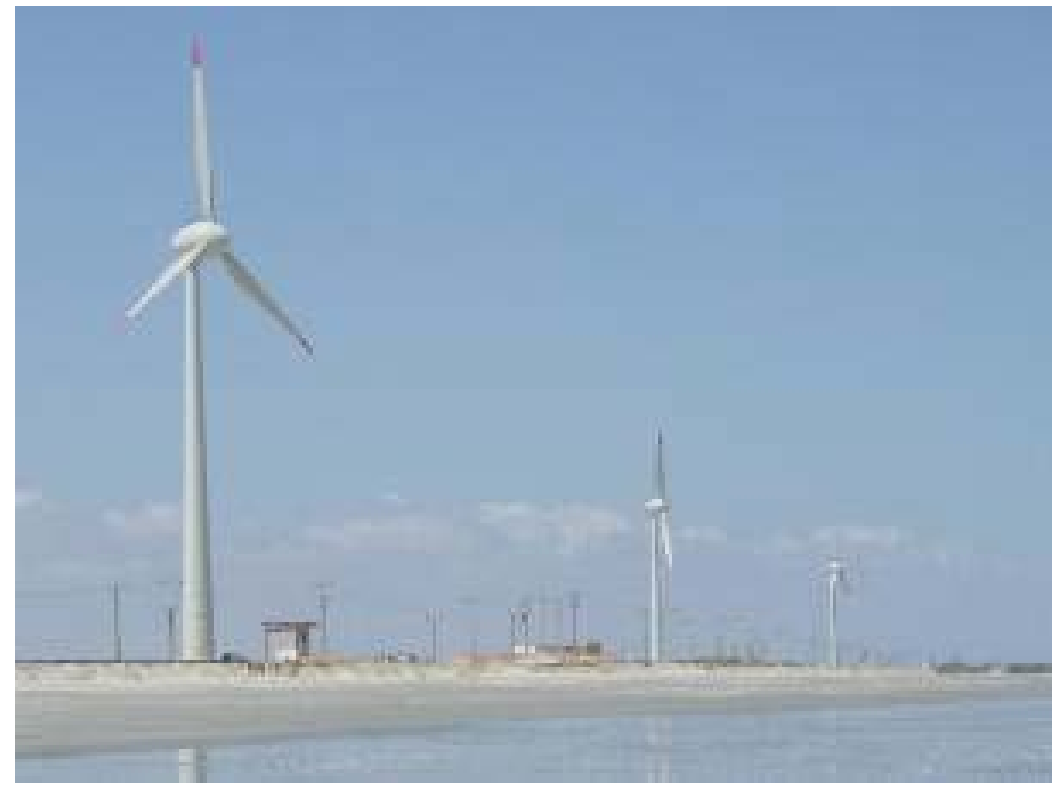

Figura 7 - Parque Eólico de Macau/RN

Conforme o exposto nas figuras acima se pode observar os dois parques eólicos instalados no Rio Grande do Norte, o que, devido a investimentos de órgãos públicos e privados, pode ser um fato concretizado no Estado.

\section{VANTAGENS E DESVANTAGENS DA ENERGIA EÓLICA}

Notadamente, como as demais energias renováveis, a energia eólica possui suas vantagens e desvantagens. Sendo que as mais importantes são diretamente ligadas ao meio ambiente, pois é absolutamente renovável, abundante e limpa. O que faz com que concluamos que não causa nenhum dano ao meio ambiente durante sua produção. Durante a construção e instalação dos aerogeradores existe a geração em níveis não preocupantes de gases do efeito estufa (GEE), porém este $\mathrm{CO}_{2}$ emitido é compensado em 6 meses de operação do 
aerogerador. (ROCHA \& ROSSI apud IMPORTA, 2008).

Citam-se ainda como vantagens, que a instalação de um parque eólico não altera em nada o lençol freático tendo em vista que não ocorrem alterações a este por deposição e lançamento como também no solo, pois não são feitas movimentações de terra, cerca de $1 \%$ do solo da área de uma parque eólico fica com seu uso impedido devido as bases dos aerogeradores, mas o que não impede que todo o solo seja utilizada para quaisquer fins. (SILVA apud IMPROTA, 2008).

Tratando sobre o sócio-econômico, no caso do Brasil, tendo em vista o seu potencial eólico existe a possibilidade da descentralização da produção de energia com vistas a suprir a necessidade de pequeno à grande porte. (ANEEL, 2004) como também a geração de empregos e renda.

Contudo, as desvantagens no uso da energia eólica também são encontradas, primeiramente temos o caso dos ruídos que tem origem mecânica ou aerodinâmica. O ruído mecânico é originado pela caixa de engrenagens, que tem como função a multiplicação da rotação das pás e funciona numa faixa de 1.000 a 1.500 rotações por minuto e o aerodinâmico pela movimentação das pás e sua vibração. Todavia, novas tecnologias já estão sendo desenvolvidas para a minimização dos ruídos com o desenvolvimento de aerogeradores com um gerador elétrico conectado diretamente ao eixo das pás e que dispensa o uso de caixa de engrenagens para a multiplicação da velocidade das mesmas. (TERCIOTE, 2002).

Um segundo impacto identificado é o visual, o que podem ser minimizados por um estudo de ordem paisagística e de observação de melhor área para instalação e construção dos parques eólicos. (FAGÁ \& RECH apud IMPROTA, 2008).

Como os aerogeradores possuem uma boa altitude e diâmetro de sua circunferência geral o acidente com aves migratórias das mais diversificadas espécies também é uma desvantagem, pois caso não haja um estudo minucioso das rotas de migração os acidentes serão inevitáveis conforme cita Terciote (2002) que em 1993, 263 turbinas de um total de 2.000 foram instaladas na Espanha dentro da rota migratória de aves e que ocasionou a morte de várias espécies dentre as quais algumas em extinção (ver figura 8).

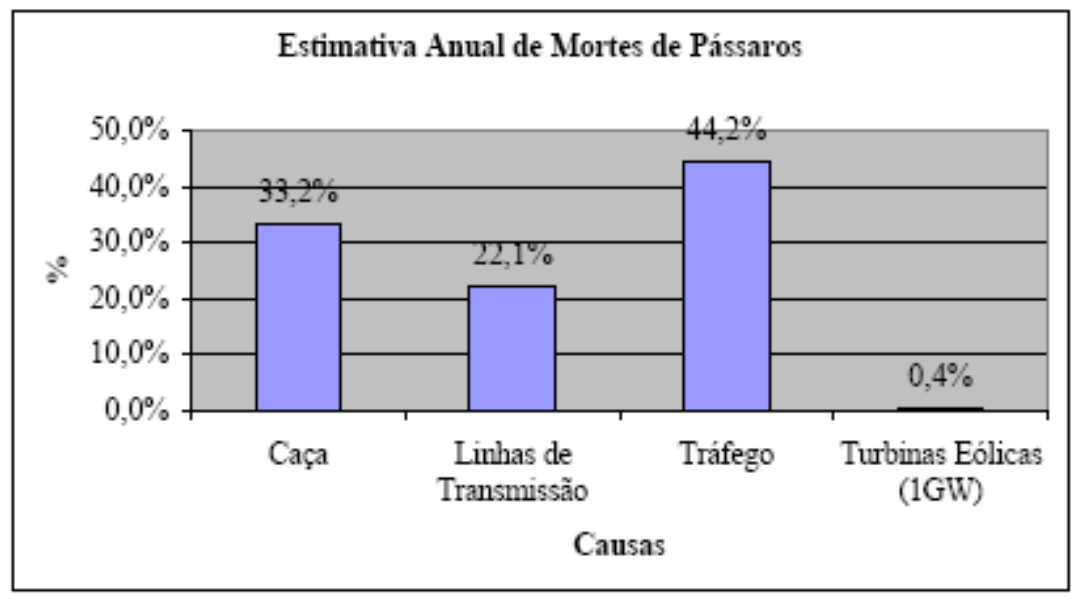

Figura 8 - Estimativa Anual de Mortes de Pássaros 
O impacto visual causado pela instalação de aerogeradores nem sempre é bem visto, todavia muitos os têm como um símbolo de sustentabilidade, ficando satisfeitos com o visual que tais elementos produzem. Os efeitos negativos que são observados são minimizados com a conscientização da população no que se refere ao uso das energias limpas e suas vantagens para a população atendida e para o meio ambiente.

\section{PERCEPÇÃO AMBIENTAL}

Para KATES 1970 (Apud GOODEY; GOLD, 1986, p. 39) as atividades na área de percepção que parece ser um termo novo, vêm sendo elaboradas a mais de 30 anos e é entendida como a sensibilização daqueles que gerenciam o ambiente por levarem em consideração os sentimentos daqueles que o usam, os estudos das percepções e atitudes são fundamentais para tornar os projetos mais efetivos, com o objetivo de assegurar sua adequação aos lugares e fornecer condições para influenciar a preferência e o gosto do público como também para estudos.

Corrobora FAGIONATO (2009) (apud GUERRA, 2008) tratando da pesquisa com base na percepção ambiental nas duas diversas formas e em sua realização podendo ocorrer com base em questionários, mapas mentais ou contorno e representação fotográfica. Existem ainda, trabalhos que buscam não apenas o entendimento do que o indivíduo percebe, mas promover a sensibilização, bem como o desenvolvimento do sistema de percepção e compreensão do ambiente.

Sendo assim, tratar sobre percepção ambiental remete-nos sucintamente ao que se percebe sobre o meio ambiente, mas não somente está simples definição. Segundo SILVA (s/d), a percepção ambiental relaciona-se diretamente entre o comportamento humano com o meio ambiente, considerando ainda tanto o ambiente construído com o natural, sendo assim, reciprocamente, tanto o comportamento humano influencia o meio ambiente como o contrário. Corrobora FAGIONATO (2009), citando que cada indivíduo percebe, reage e responde diferentemente frente às ações sobre o meio. Pois suas respostas ou ações são resultado das percepções, julgamentos e esperanças de cada indivíduo. Vale ressaltar que nem todas as manifestações são claras, na maioria das vezes, são inconscientes e passam a fazer parte do nosso dia-a-dia, aceitando-as ou não.

Visando-se os ambientes, sejam estes, por exemplo, rurais ou urbanos, podemos observar vários aspectos que direta ou indiretamente influenciam nossa percepção sobre o meio, citando-se a criminalidade, as favelas, a falta de educação, o barulho de grandes indústrias, a fumaça de chaminés, o acesso a saúde etc. Tendo em vista que sabendo como as pessoas percebem e vivem em seu meio ambiente, com suas satisfações e insatisfações, poderar-seà desenvolver trabalhos com base na percepção ambiental. (FAGIONATO, 2009).

\section{A PERCEPÇÃO DA POPULAÇÃO DE CURRAIS NOVOS NO QUE TANGE A ENERGIA EÓLICA}

A apresentação dos resultados sobre os questionamentos realizados à amostra populacional de Currais Novos dar-se-á por meio de gráficos e análise qualitativa das questões abertas. O questionário ora aplicado foi divido em três grupos principais de perguntas, citando as questões gerais (Sexo, Faixa Etária e Escolaridade), questões sobre a participação e relação 
com as causas ambientais (Práticas de Sustentabilidade, Atitudes e Degradação Ambiental) e ainda questões específicas sobre a energia eólica (conhecimento, importância, tipos, existência no Rio Grande do Norte, Potencial Brasileiro e Municipal, Melhorias e incômodo visual). Sendo assim, apresentam-se a seguir as informações obtidas.

\section{QUESTIONAMENTOS GERAIS}

Os questionamentos gerais identificam, na amostra, o sexo dos respondentes, a idade do entrevistado e ainda o nível de escolaridade do mesmo, observa-se assim heterogeneidade entre os respondentes tendo em vista os dados apresentados a seguir.

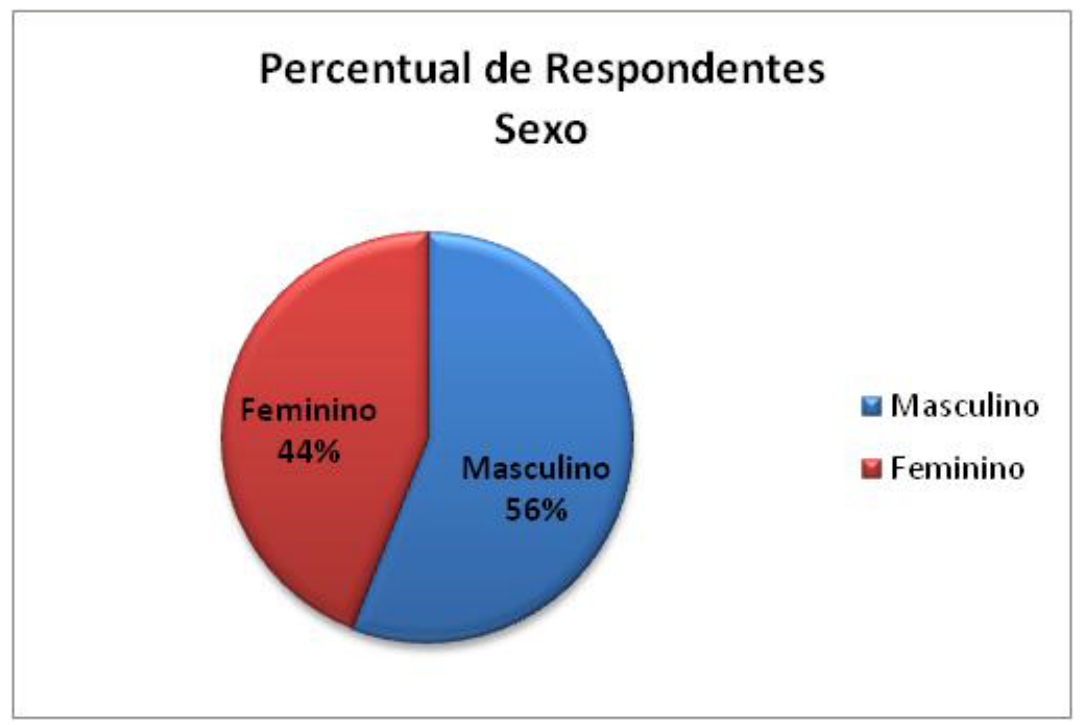

Figura 9 - Percentual de Respondentes - Categoria Sexo

Pode-se observar um bom grau de equilíbrio com relação aos respondentes no quesito sexo, pois se observa que $56 \%$ dos respondentes são do sexo masculino e $44 \%$ do sexo feminino. Tal dado contraria a estimativa do Estado e do Brasil com relação à população feminina ser predominantemente maior que a masculino.

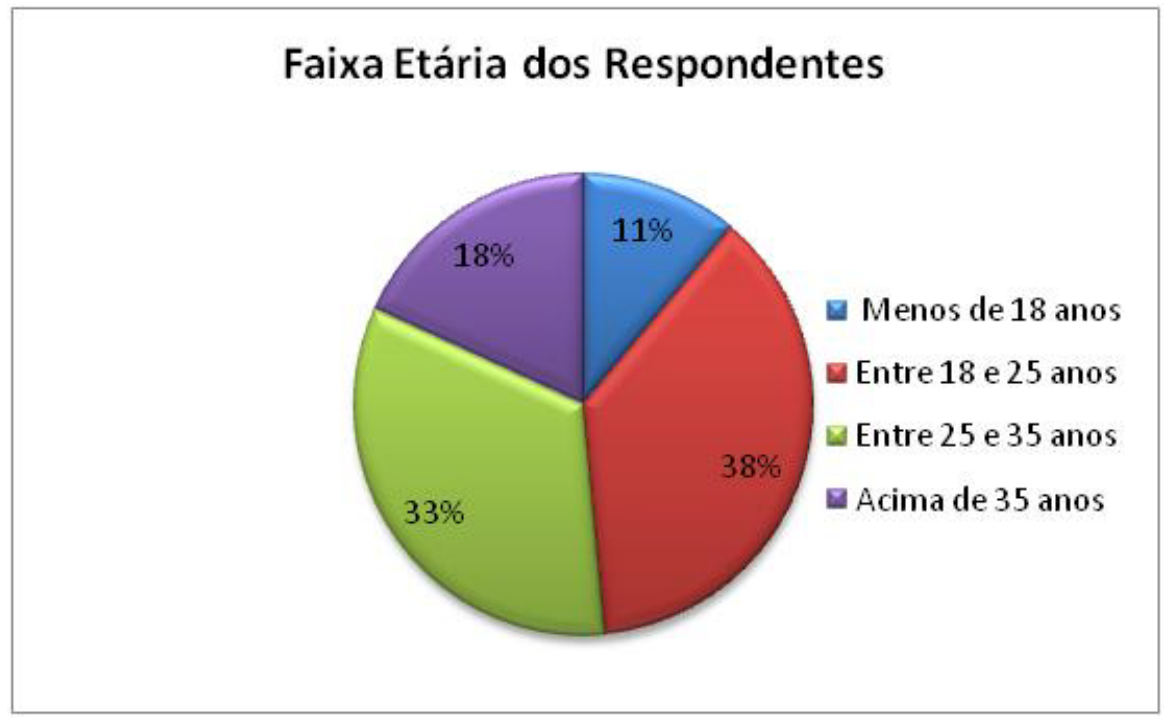

Figura 10 - Faixa Etária dos Respondentes 
Procurou-se, na medida do possível, obter informações de todas as faixas etárias da população Curraisnovense como o exibido no gráfico acima, onde, na oportunidade, podese observar que $51 \%$ dos respondentes têm mais de 25 anos.

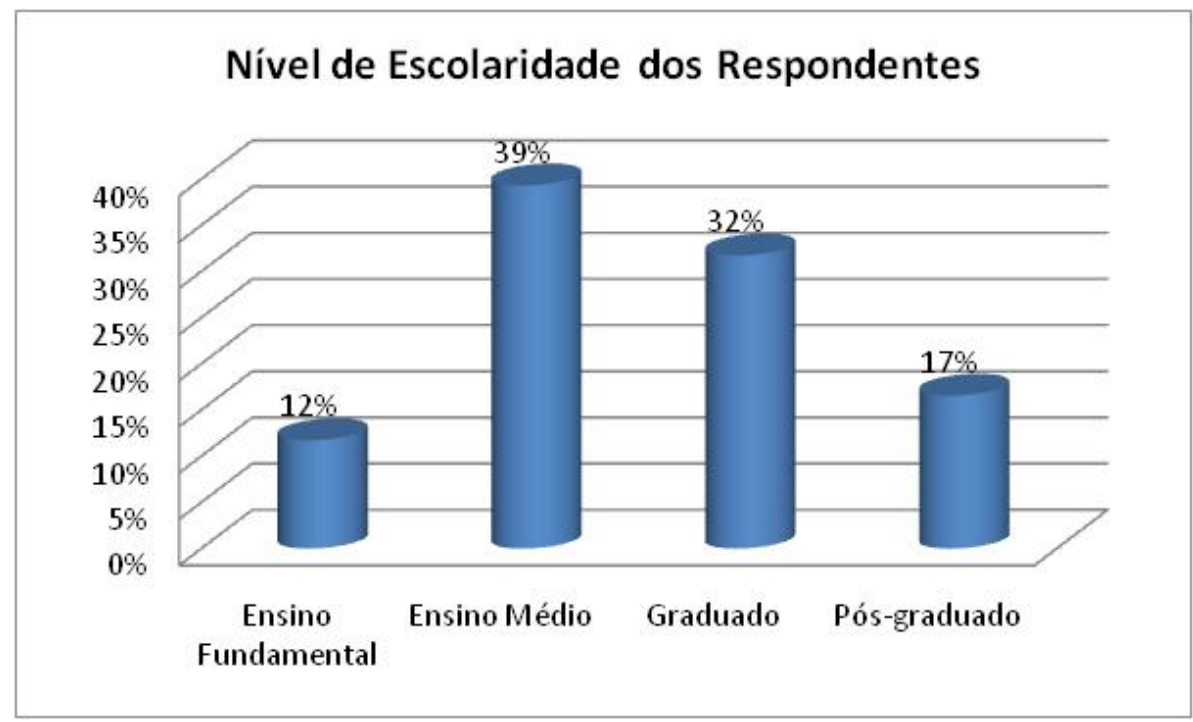

Figura 11 - Nível de Escolaridade

Conforme se averigua no gráfico apresentando, que trata sobre o nível de escolaridade dos respondentes, temos uma amostra de $49 \%$ de pessoas graduadas e pós-graduadas, o que muito representa, tendo em vista a imparcialidade dos mesmos, devido ao grau de ensino. Neste sentido, as análises obtidas neste trabalho é representativa de um segmento da população jovem e bem escolarizada, fato interessante para a pesquisa, pois há sempre a impressão de que os mais letrados são também mais conscientes ambientalmente.

\section{QUESTIONAMENTOS SOBRE A PARTICIPAÇÃO E RELAÇÃO COM A CAUSA AMBIENTAL}

Com relação aos questionamentos sobre a participação e relação com a causa ambiental, procurou-se identificar nos respondentes seu grau de participação junto à causa ambiental e assim inferir relacionando ações e reações dos mesmos.

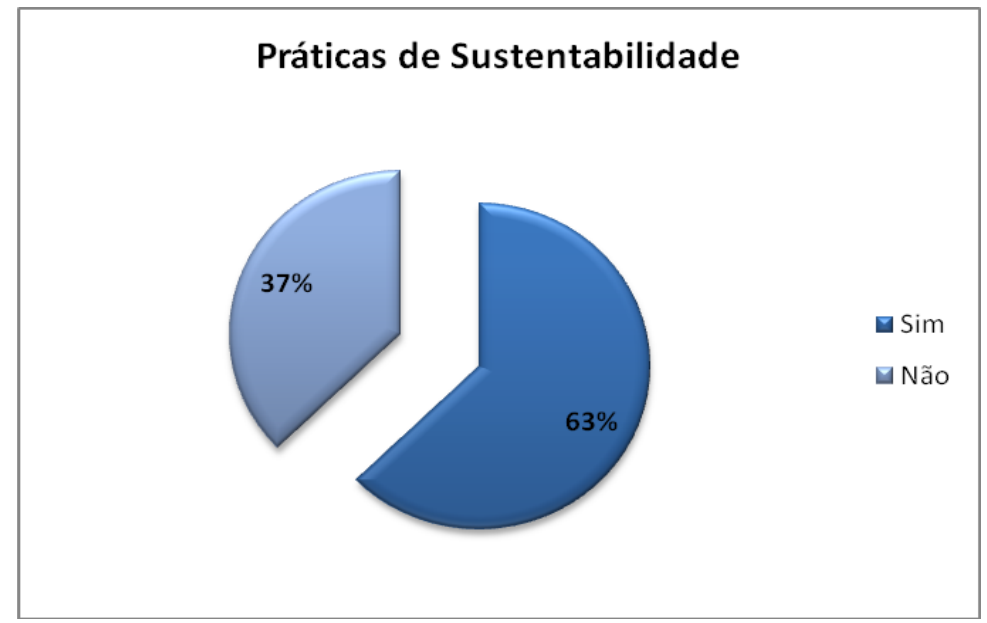

Figura 12 - Utilização de práticas de sustentabilidade na residência ou trabalho dos respondentes 
Considerando a importância das práticas de sustentabilidade no dia-a-dia de todos, os respondentes foram questionados sobre a utilização destas práticas em suas residências ou empregos, tal questionamento versou sobre a economia de matéria prima, água, energia, coleta seletiva entre outros conforme pode ser observado no questionário em anexo. Observou-se assim, que mais de $60 \%$ dos respondentes realizam pelo menos uma destas ações, a maioria informalmente relatou que quando se trata de economia financeira tem-se um incentivo maior para economia de água e energia em suas residências. Entretanto, ainda temos uma significativa representatividade daqueles que não aderem a práticas de sustentabilidade. Vale destacar que no tocante aos tipos de atitudes contra a degradação ambiental a maioria dos entrevistados afirmou não fazer nada, o que representa uma contradição quanto a preocupação com a sustentabilidade ambiental, revelada no quesito anterior.

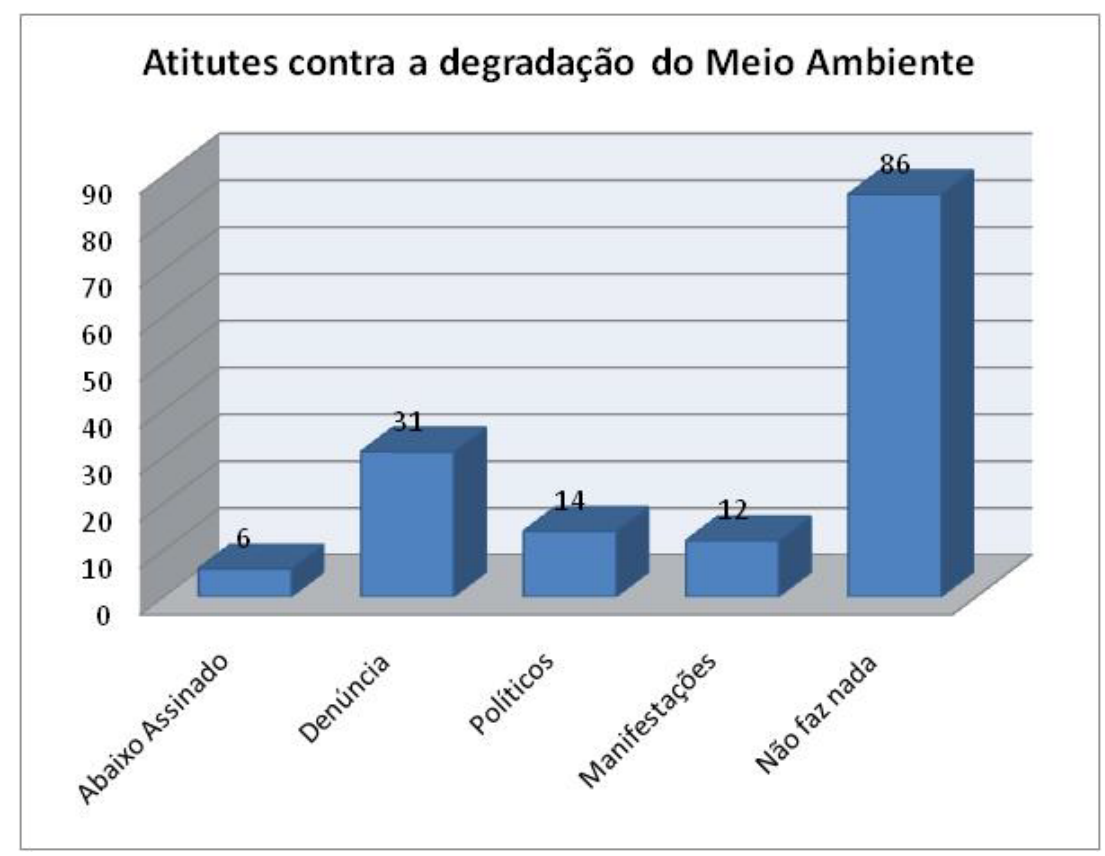

Figura 13 - Atitudes tomadas contra a degradação do Meio Ambiente

Quando questionados sobre as atitudes que tomam contra a degradação do meio ambiente no município, tal pergunta de múltipla escolha, observamos que 86 dos respondentes "não fazem nada”, ou seja, não tomam qualquer atitude para mitigar as ações que agridem o meio ambiente em Currais Novos. O que demonstra que ações de educação ambiental devem acontecer para que a população enquanto maior fiscalizadora dela mesma seja uma força ativa no controle de tais atividades. 


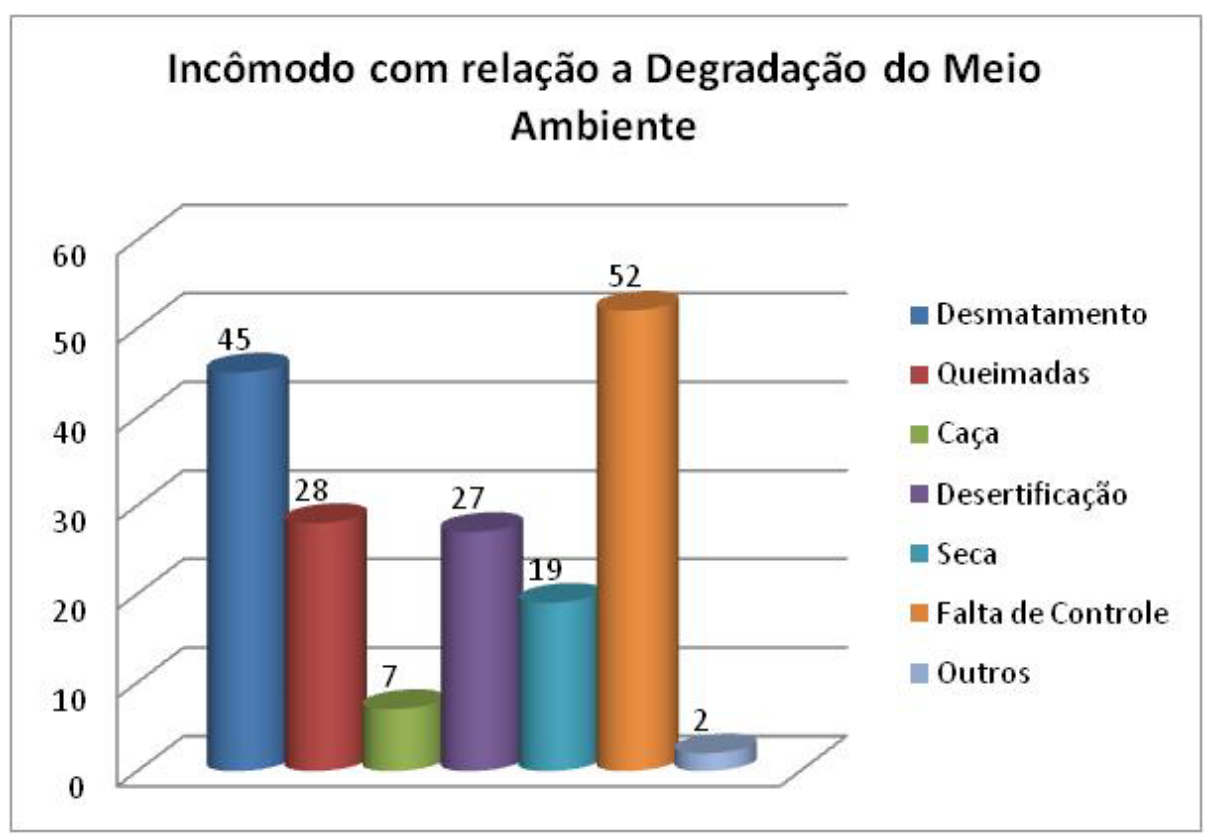

Figura 14 - Incômodo com relação a Degradação do Meio Ambiente no Município

O questionamento apresentado no gráfico acima apresenta de forma quantitativa, por se tratar de pergunta com mais de uma opção para escolha, a percepção dos respondentes com relação ao que mais o incomoda no que tange a degradação do meio ambiente no município de Currais Novos, observa-se que a falta de controle dos órgãos de meio ambiente e o desmatamento os quais tem papel significativo quando da abordagem de tal temática, em segundo lugar podemos apresentar as queimadas e desertificação que é uma conseqüência das ações antrópicas na maioria das vezes.

\section{QUESTIONAMENTOS ESPECÍFICOS COM RELAÇÃO ÀS ENERGIAS RENOVÁVEIS COM FOCO NA ENERGIA EÓLICA}

Tais questionamentos, denominados neste capítulo de específicos, versam exclusivamente sobre o foco do artigo, a energia eólica, os mesmos consistem de peça fundamental para a análise efetiva da percepção ambiental da população e assim servirem de ferramenta para a inferência nos resultados ora esperados.

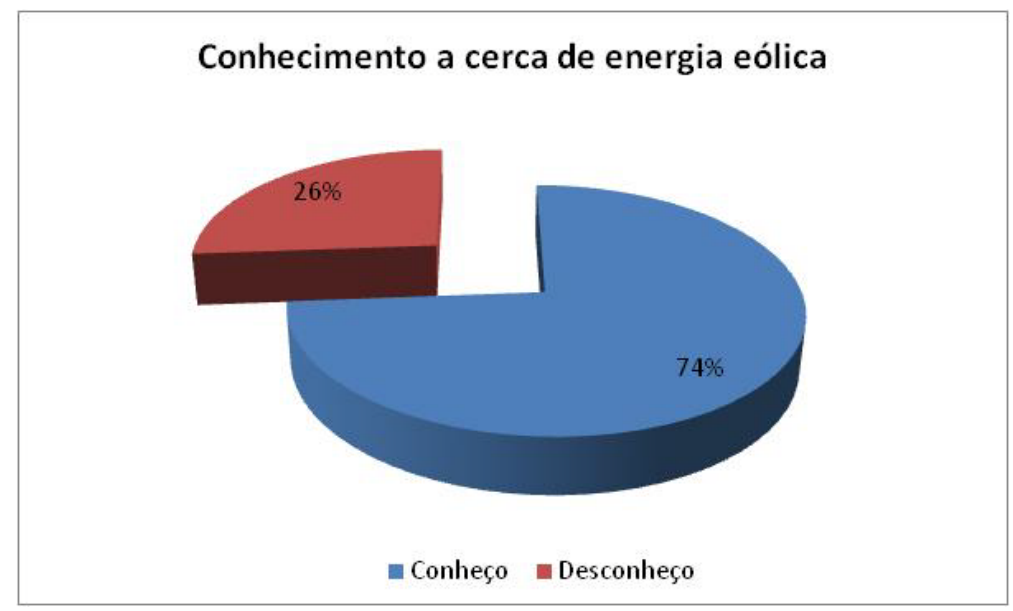

Figura 15 - Conhecimento da população de Currais Novos a cerca da Energia Eólica 
Tal questionamento versou principalmente sobre o conhecimento que os respondentes tem a cerca da energia eólica, tratando principalmente sobre o funcionamento, instalação, vantagens e desvantagens de tal energia. Pode-se observar, conforme apresentado, que 74\% dos entrevistados conhecem a energia eólica.

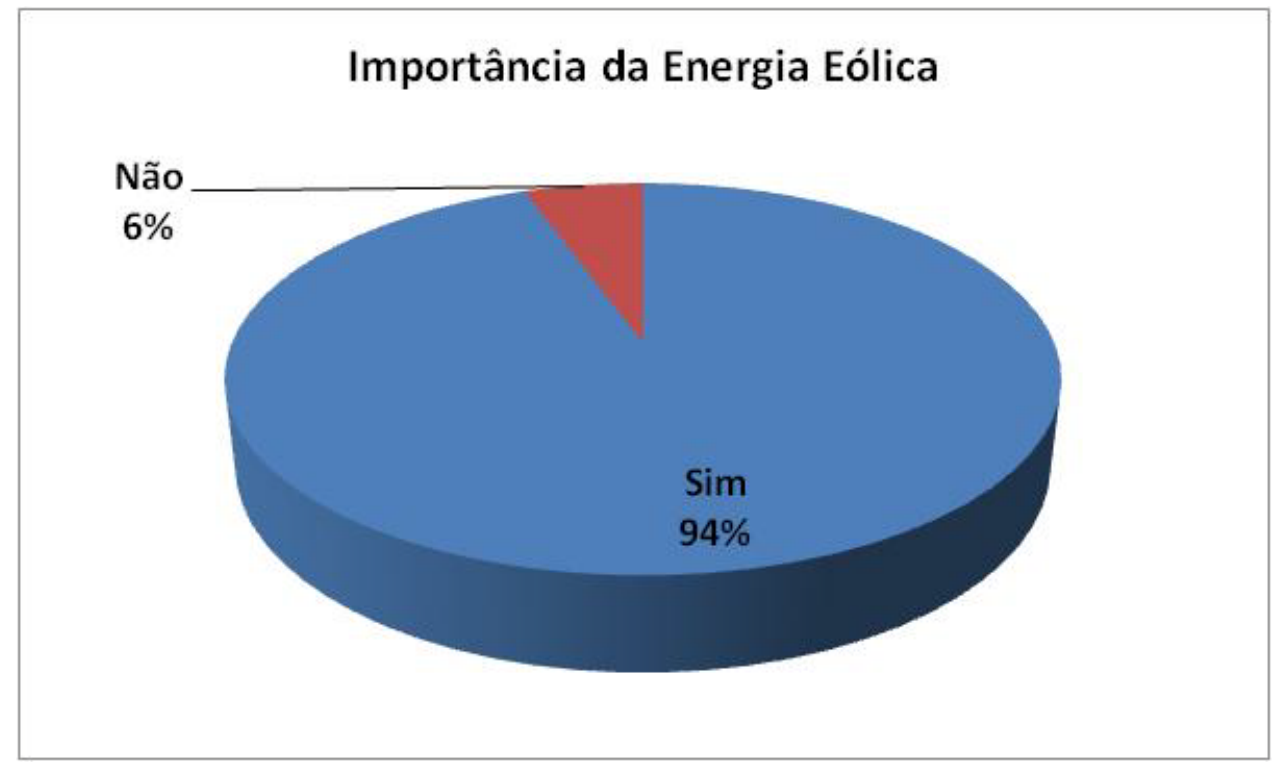

Figura 16 - Importância da Energia Eólica

Observa-se na apresentação gráfica acima, que a população afere um significativo grau de importância a energia eólica, muitos por ocasião da aplicação dos questionários, citaram que devido a sua eficiência, as energias renováveis, neste caso a eólica, será uma das saídas para a crise energética no país e no mundo, tendo em vista as condições climáticas nas quais está inserido o Brasil.

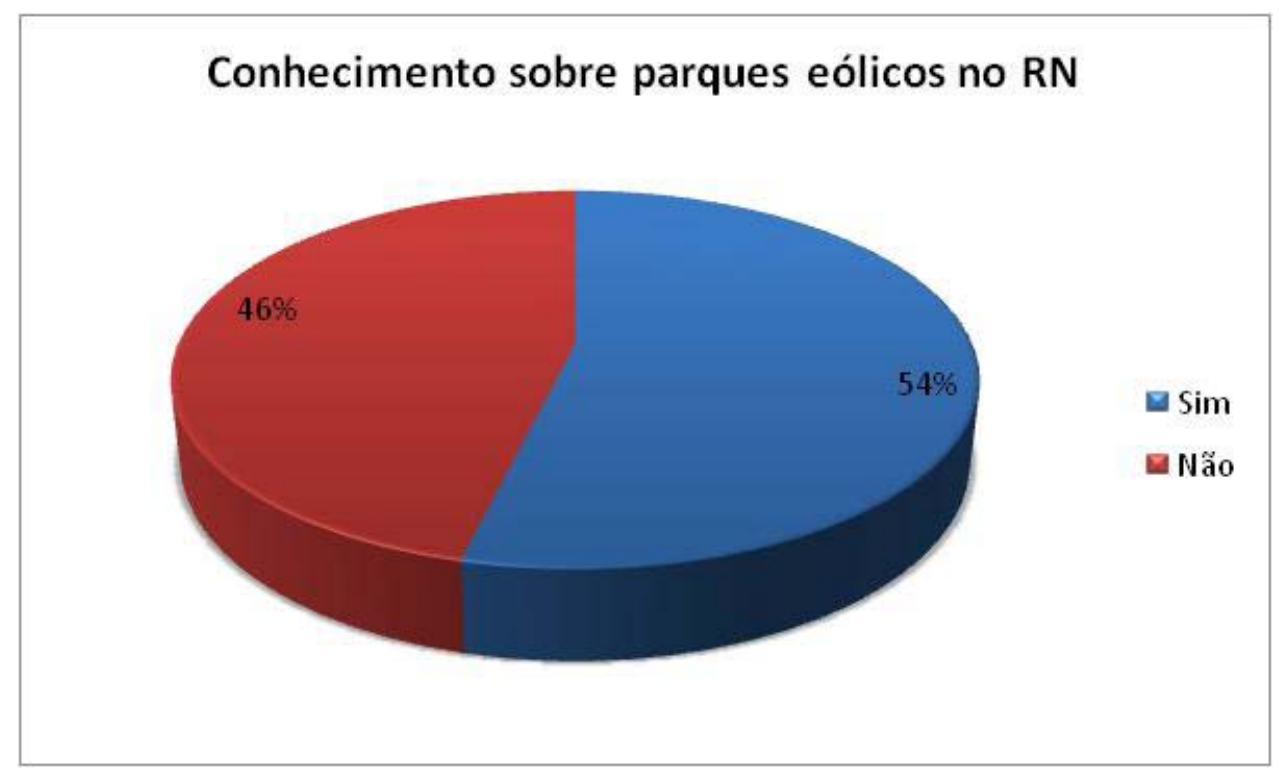

Figura 17 - Existência de parques eólicos no Rio Grande do Norte

Um dado que surpreendentemente foi apresentando é com relação aos questionamentos sobre a existência de parques eólicos no Estado do Rio Grande do Norte, conforme apresentado $46 \%$ da população desconhece a existência dos mesmos, dado este que pode 
ser aumentado devido aos respondentes que marcaram "sim" no questionamento sobre a localização, mas não citaram o local de funcionamento de tais parques, muitos citavam que sabiam que existia, mas não sabia precisar a localização dos mesmos.

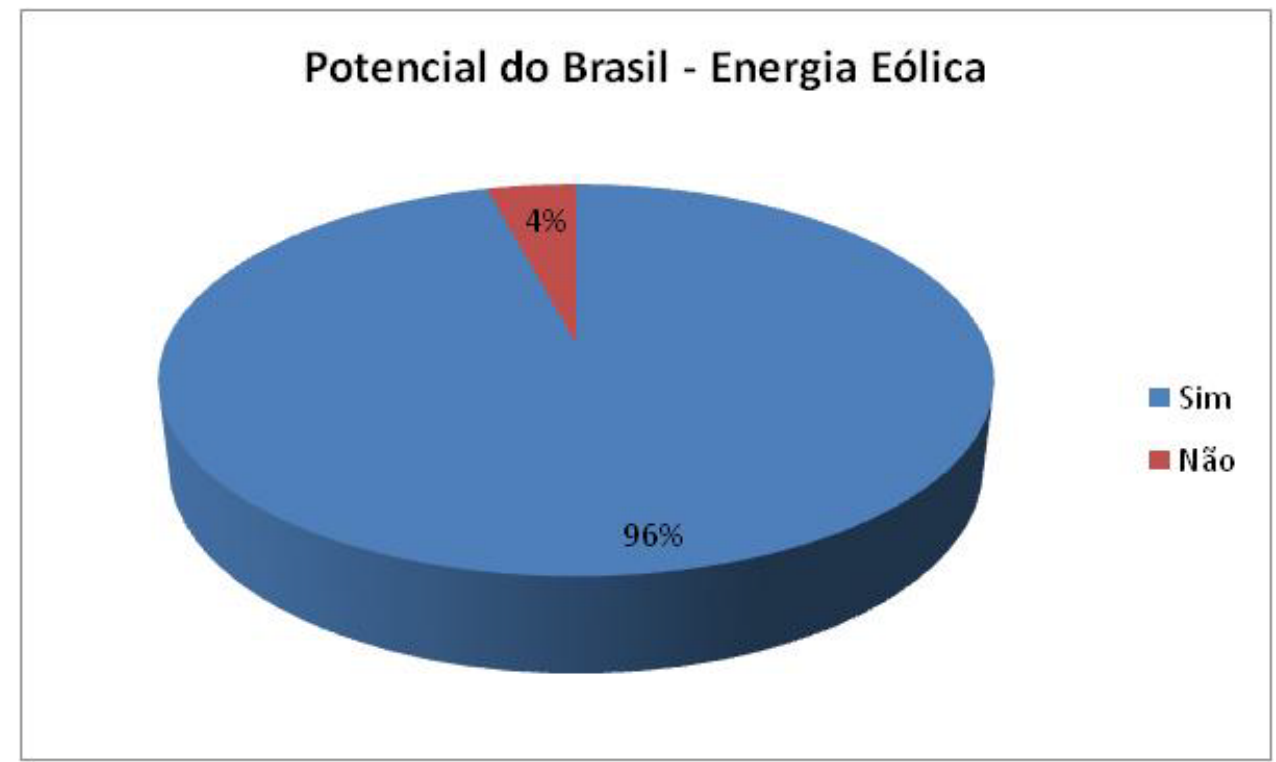

Figura 18 - Percepção sobre o potencial da Energia Eólica no Brasil

A amostra pesquisada apresenta um significativo grau de confiabilidade no que tange o potencial brasileiro sobre a energia eólica, $96 \%$ dos entrevistados consideram que o Brasil tem potencial para inserir em sua matriz energética a energia eólica como contribuinte para a produção de energia elétrica.

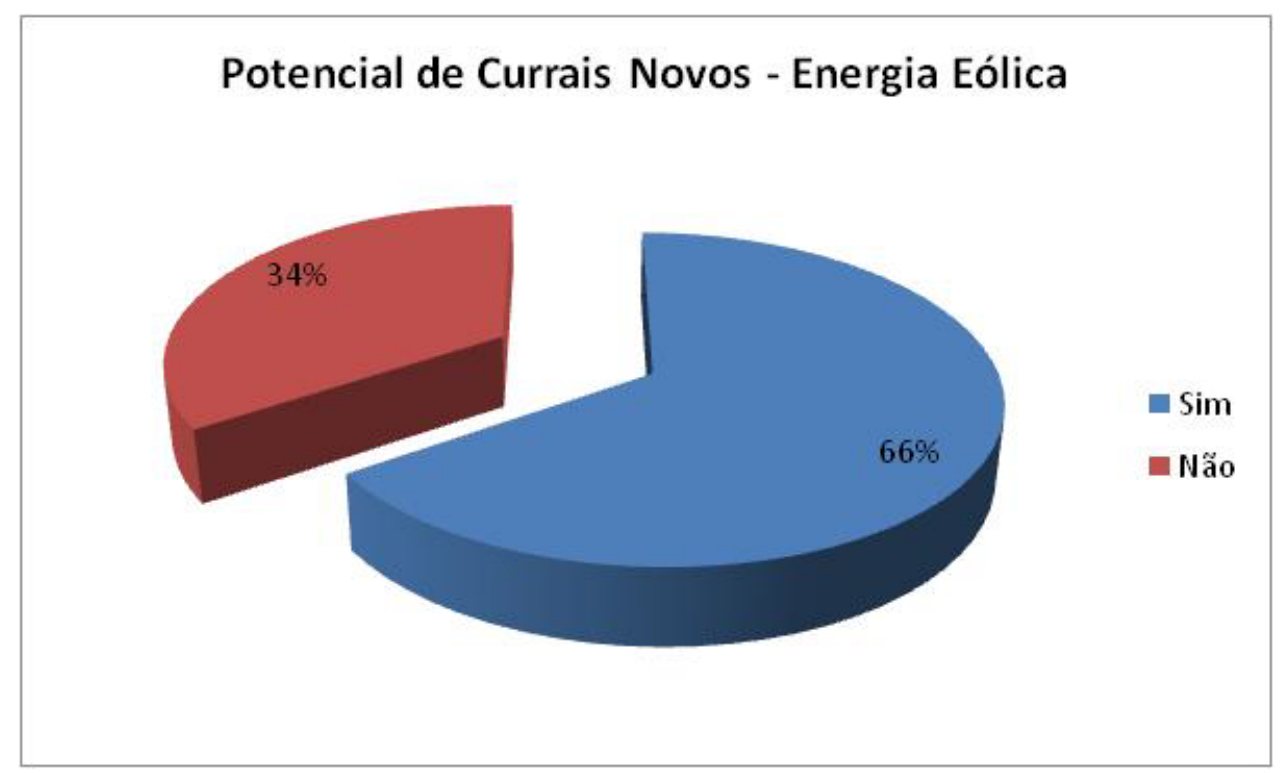

Figura 19 - Percepção sobre o potencial Curraisnovense com relação à Energia Eólica

Seguindo a tendência do gráfico anteriormente apresentado, 83\% dos respondentes afirmam que o município de Currais Novos, apresenta condições (potencial) para a instalação de um parque eólico. 


\section{Melhoria da Matriz Energética Brasileira com a inserção de Energia Renováveis}

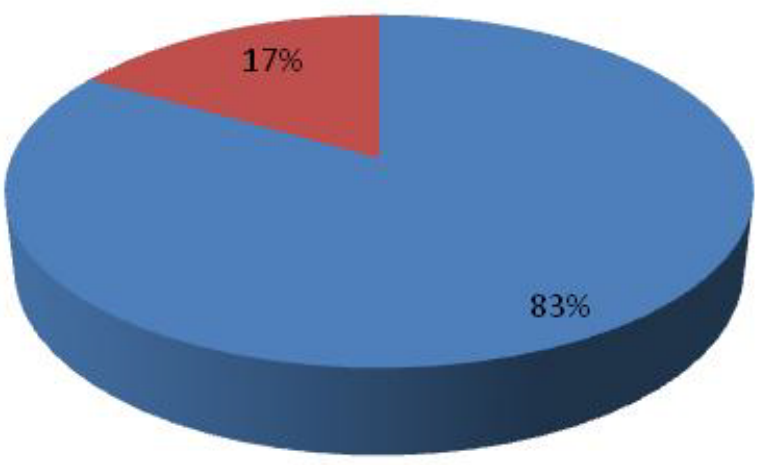

- Sim

- Não

Figura 20 - Considerações sobre a melhoria da matriz energética brasileira com a inserção de energias renováveis, neste caso a eólica.

Na mesma percepção anteriormente apresentada, 83\% dos questionados conferem segurança a inserção de energia renováveis, neste caso a eólica, como ponto de melhoria da matriz energética brasileira.

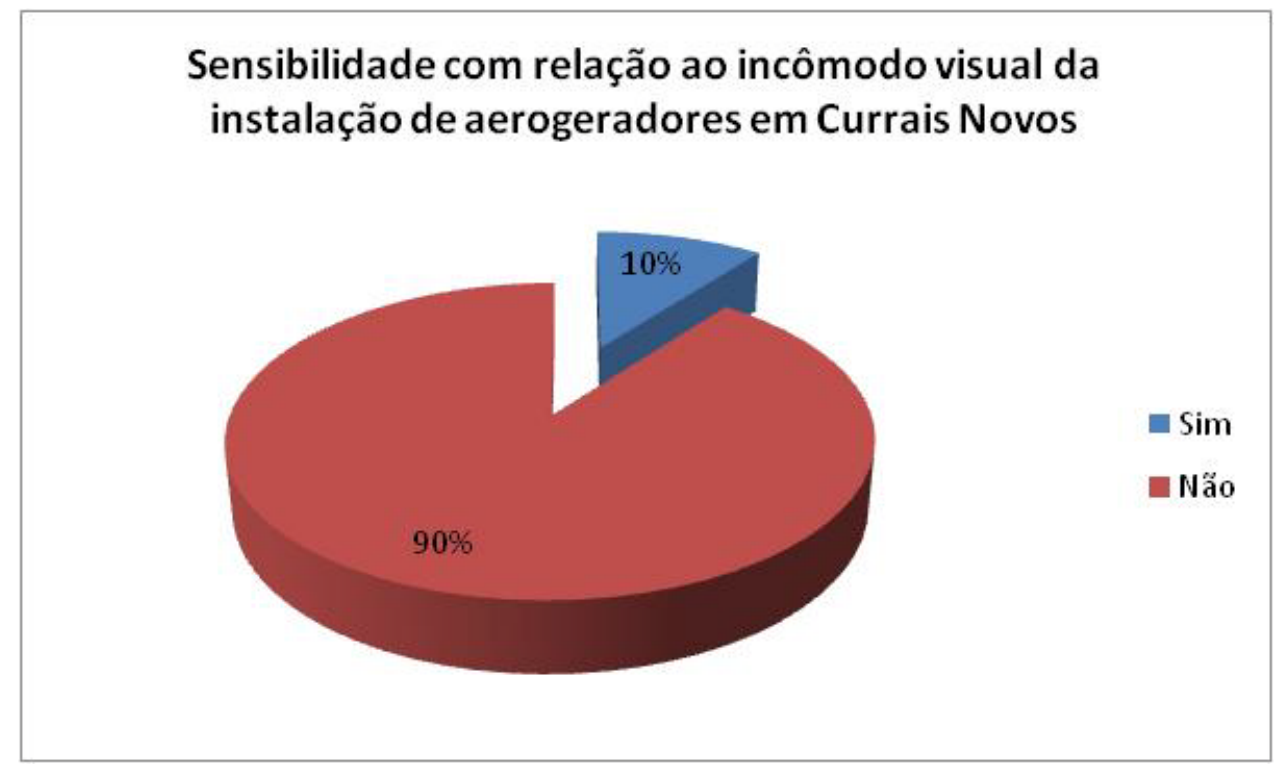

Figura 21 - Sensibilidade visual com relação à instalação de aerogeradores no município de Currais Novos

A aplicação do questionário apresentou de forma clara o questionamento sobre a percepção (sensibilidade) da população curraisnovense no que tange a instalação de aerogeradores no município, dado que mostra a abertura da população para tal empreendimento, $90 \%$ dos entrevistas relatam que não seriam incomodados com a instalação de um parque eólico no município, informalmente relataram que seria a solução para a constantes quedas de energia e apagões. 


\section{CONCLUSÃO}

Observou-se, com a pesquisa, ora realizada, que a população Curraisnovense apresenta um grau significativo de sensibilidade no que versa sobre as energias renováveis, principalmente a eólica, tais assertivas são corroboradas pela apresentação dos gráficos acima que demonstram percentualmente e qualitativamente tal abertura.

Fazendo-se, ainda, uma correlação entre os questionamentos pode-se observar que cerca de $24 \%$ da população curraisnovense desconhece a energia eólica em seu funcionamento, utilização e instalação, mas $96 \%$ a consideram importante, o que realmente é um dado importante, pois apresenta mesmo pelo desconhecimento uma visão de sensibilidade no tratamento das questões que envolvam as melhorias na geração de energia elétrica a partir da força dos ventos. Um fato que vale ser ressaltado é que os respondentes desconhecem a localização exata dos parques eólicos no Estado, mas citaram informalmente que estes existem devido a notícias que já viram ou leram em algum material informativo.

Quanto a questão da sustentabilidade é tratada, geralmente os respondentes que não praticam a sustentabilidade em suas residências ou trabalho também não realizam ações contra a degradação ambiental, um ponto que deve ser mudado rapidamente tendo em vista que as ações de sustentabilidade garantirão certamente um futuro mais adequado para toda humanidade.

Inferindo-se sobre os respondentes com ensino fundamental (grau de escolaridade), geralmente, os mesmo, não acreditam no potencial do Brasil e do município com relação a energia eólica, o que demonstra, parcialmente, que o nível escolar influi diretamente quando se tem que opinar sobre situações que versam sobre um maior grau de conhecimento sobre a realidade a qual se está inserido. Já os graduados e pós-graduados apresentam grande preocupação com o controle do órgãos ambientais, tendo em vista a falta de ações e investimentos na área e atuações dos mesmos. E ainda, as mulheres são mais atuantes na implantação de práticas de sustentabilidade em suas residências ou trabalho o que pode ser avaliado pelas mesmas serem maioria da população do estado e do Brasil.

Espera-se ainda, que brevemente, e pela importância da inserção das energias renováveis na matriz energética mundial e principalmente na Brasileira, que tais ações passem a fazer parte do dia-a-dia do município de Currais Novos, pois pelas suas características geomorfológicas e climatológicas tem-se um grande potencial para a inserção da energia eólica na Cidade.

\section{REFERÊNCIAS}

1. AGÊNCIA NACIONAL DE ENERGIA ELÉTRICA. Atlas da energia elétrica do Brasil. Disponível em: < http://www.aneel.gov.br/visualizar_texto.cfm?idtxt=1689>. Acesso em: 1 abr. 2009.

2. GIL, Antônio Carlos. Metodologia da Pesquisa. 8 ed. São Paulo. Atlas, 2002.

3. COLLE, Sérgio. Energias renováveis, meio ambiente e políticas públicas de ciência e tecnologia. Disponível em: http://www2.desenvolvimento.gov.br/arquivo/sti/publicacoes/futAmaDilOportunidades /rev20011219 02.pdf $>$. Acesso em: 10 maio 2009.

4. ENERGIAS renováveis. Disponível em: <http://www.ider.org.br/oktiva.net/1365/nota/17354/>. Acesso em: 6 maio 2009. 
5. ESTIMATIVA de contagem populacional. Disponível em: $<$ http://www.ibge.gov.br/home/estatistica/populacao/contagem2007/contagem_final/ta bela1_1_11.pdf > . Acesso em: 6 maio 2009.

6. FAGIONNATO, Sandra. Percepção ambiental. In: Educação ambiental através da visão integrada de bacia hidrográfica via internet. Disponível em: < http://educar.sc.usp.br/biologia/textos/m_a_txt4.html >. Acesso em: 1 abr. 2009.

7. FEITOSA, Everaldo Alencar. Sustentabilidade na geração e uso de energia no Brasil: os próximos 20 anos. Disponível em: <www.cgu.unicamp.br/energia2020/Palestra\%20Unicamp.ppt $>$. Acesso em: 10 maio 2009.

8. GALDINO, Marco A. E.; LIMA, Jorge H. G.; RIBEIRO, Cláudio M.;Eduardo T. SERRA. O Contexto das Energias Renováveis no Brasil. Disponível em: <www.cresesb.cepel.br/publicacoes/download/Direng.pdf>. Acesso em: 22 abr. 2009.

9. GOODEY, Brian; GOLD, Jonh. Geografia do comportamento e da percepção. Minas Gerais: Publicação Especial, 1986.

10. IMPROTA, Rafaella Lenoir. Implicações socioambientais da construção de um parque eólico no município de Rio do Fogo - RN. 2008. Dissertação (Mestrado em Psicologia)- Universidade Federal do Rio Grande do Norte, Natal, 2008.

11. JANNUZZI, Gilberto de Martino. Energia e mudanças climáticas: barreiras e oportunidade para o Brasil. Revista Comciência, São Paulo, N. 109, 2005. Disponível em: < http://www.comciencia.br/reportagens/clima/clima13.htm.>. Acesso em: 03 jun. 2009.

12. LEAL, Maria do Carmo. et al. Saúde, ambiente e desenvolvimento: processos e consequências sobre as condições de vida. Rio de Janeiro: Hucitec, 1992.

13. MACEDO, Isaias Carvalho de. Estado da arte e tendências tecnológicas para energia. In: Secretaria Técnica do Fundo Setorial de Energia. Disponível em: < http://www.finep.gov.br/fundos_setoriais/ct_energ/documentos/ctenerg03estado_arte.pdf $>$. Acesso em: 1 abr. 2009.

14. MAIOR aerogerador do mundo. Disponível em: $<$ http://www.renovaveis.tecnopt.com/o-aerogerador-maior-do-mundo-com-7-mw/>. Acesso em: 7 jun. 2009.

15. O PARQUE eólico de Rio do Fogo poderá ser ampliado. Disponível em: $<$ http://tribunadonorte.com.br/motoresrn/noticias.php?id=83876 $>$. Acesso em: 5 maio 2009.

16. OLINTO, Cláudio Rodrigues; SANTOS, Sônia Magalhães do. Aproveitamento da energia dos ventos. Disponível em: $<$ http://termo.furg.br/claudio/energia\%20eolica/Energia\%20eolica.pdf $>$. Acesso em: 2 jun. 2009.

17. PARQUE eólico de Macau. Disponível em:

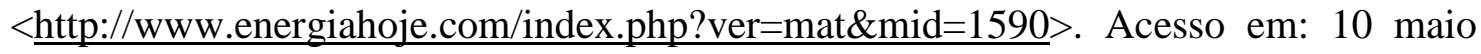
2009.

18. PASSOS, Júlio César. Energias renováveis: energia eólica. Florianópolis: UFSC, 2008. Disponível em: <http://www.lepten.ufsc.br/disciplinas/emc5483/eolica1.pdf>. Acesso em: 5 abr. 2009.

19. PESSOA, Viviany Silva. Conhecimento sobre energia eólica: um estudo exploratório a partir das redes semânticas naturais de estudantes da cidade de Natal-RN. Dissertação (Mestrado em)- Universidade Federal do Rio Grande do Norte. Disponível em: <www.bczm.ufrn.br>. Acesso em: 12 abr. 2009.

20. SILVA, Abelardo Vinagre da. Psicologia ambiental: características gerais, aspectos metodológicos e campo de atuação. Disponível em: $<$ h 
http://www2.desenvolvimento.gov.br/arquivo/sti/publicacoes/futAmaDilOportunidades /rev20011219_02.pdfttp://abelardo2000.sites.uol.com.br/page2.html>. Acesso em: 1 abr. 2009.

21. TERCIOTE, Ricardo. Análise de eficiência de um sistema eólico isolado. Dissertação (Mestrado em Planejamento de Sistemas Enérgicos)- Universidade Estadual de Campinas. Disponível em: <http://libdigi.unicamp.br/document/?code=vtls000252318>. Acesso em 4 mai. 2009. 